\title{
STUDI KASUS IMPLEMENTASI SERVICE ORIENTED ARCHITECTURE (SOA) DI CREDIT SUISSE
}

\author{
Sartika Kurniali \\ Information Systems Department, School of Information Systems, Binus University \\ Jl. K.H. Syahdan No. 9, Palmerah, Jakarta Barat 11480 \\ SartikaKurniali@binus.edu
}

\begin{abstract}
Credit Suisse Group (CSG) is a leading company engaged in global financial services. At the end of 90s IT infrastructure complexity of Credit Suisse has reached a critical situation. The existing IT infrastructure is no longer able to support the required business functionality. This leads to the introduction of an integrated architecture based on Service-Oriented Architecture (SOA). The purpose of this study is to learn how Credit Suisse successfully implements SOA both on a technical and organizational level. Analyses were performed by processing factual and reference data acquired.

From the research, the successful implementation is due to clarity of interface, clarity of process, management commitment, and solid technology. Their success does not come easily since they also face obstacles and conflicts on the implementation.
\end{abstract}

Keywords: service-oriented architecture (SOA), service, reuse

\begin{abstract}
ABSTRAK
Credit Suisse Group (CSG) adalah perusahaan terkemuka yang bergerak pada jasa finansial secara global. Pada akhir tahun 90-an kompleksitas infrastruktur IT Credit Suisse telah mencapai situasi kritis. Infrastruktur IT yang sudah ada tidak lagi dapat mendukung fungsionalitas bisnis yang diperlukan. Hal ini membuat dikenalkannya sebuah arsitektur yang terintegrasi berdasarkan Service-Oriented Architecture (SOA). Tujuan penelitian ini adalah mempelajari bagaimana Credit Suisse sukses melakukan implementasi SOA baik pada level organisasi maupun teknis. Analisis dilakukan dengan mengolah data faktual yang didapatkan dan referensi. Dari hasil penelitian, kesuksesan implementasi karena kejelasan interface, kejelasan proses, komitmen manajemen, dan teknologi yang solid. Kesuksesan juga tidak didapat dengan mudah karena implementasi juga menghadapi kendala dan konflik.
\end{abstract}

Kata kunci: service-oriented architecture (SOA), service, penggunaan kembali 


\section{PENDAHULUAN}

Credit Suisse Group (CSG) adalah perusahaan terkemuka yang bergerak pada jasa finansial secara global yang berpusat di Zurich. Unit bisnis pelayanan finansial Credit Suisse menangani klien pribadi dan perusahaan kecil dan menengah dengan pelayanan bank pribadi dan konsultasi finansial, produk bank, dan pensiun dan asuransi dari Winterthur. Bisnis unit Credit Suisse First Boston, sebuah bank investasi melayani institusi global, perusahaan, dan klien individu dan berperan juga sebagai perantara finansial. Saham Credit Suisse Group didaftarkan di Switzerland dan New York. Grup ini memperkerjakan sekitar 60.000 karyawan dan beroperasi di lebih dari 50 negara. Pada 31 Maret 2004, asetnya telah mencapai CHF 1.241,3 milliar.

Namun Credit Suisse mengalami masalah klasik karena middleware overload yang disebabkan terlalu banyaknya produk dan koneksi point-to-point. Skenario yang akhirnya menciptakan situasi "integration spaghetti" (Istilah yang dipakai Gartner) (Herr, Bath, \& Koschel, 2004), membuat mereka melakukan perubahan di satu sistem yang bisa memiliki efek berkelanjutan, yang hasilnya tidak bisa diperkirakan karena setiap departemen memiliki sistem sendiri seperti pada Gambar 1.

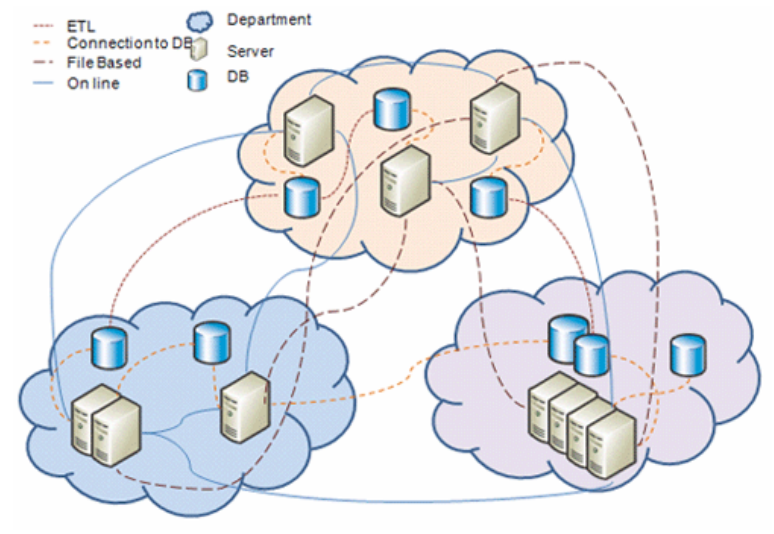

Gambar 1 Tipikal integration spaghetti di Perusahaan

Credit Suisse tidak puas dengan model integrasi point-to-point yang hanya menyelesaikan masalah per proyek. Hal ini telah membuat pengembangan aplikasi baru sangat kompleks dan terkadang tidak mungkin dilakukan.

Pada akhir tahun 90-an, kompleksitas infrastruktur IT telah mencapai situasi kritis. Bahkan tidak lagi dapat mendukung fungsionalitas bisnis Credit Suisse. Solusi ad hoc untuk mengintegrasikan sistem IT setelah merger dan akuisisi pun tidak sukses.

Pertumbuhan fungsionalitas bisnis Credit Suisse yang tidak bisa lagi didukung oleh infrastruktur IT telah mendorong dikenalkannya sebuah arsitektur yang terintegrasi berdasarkan Service-Oriented Architecture (SOA) ke dalam perusahaan. Pindah dari sistem mainframe ke arsitektur berorientasi layanan (SOA) yang menggunakan layanan web menarik dilakukan, tetapi menakutkan (Rodriguez et al., 2013). Implementasi SOA pun diterapkan pada level organisasi dan teknis. Dengan pendekatan implementasi proyek pilot, Credit Suisse telah berhasil mengimplementasikan tiga service bus yang berbeda untuk bisa memenuhi kebutuhan berbeda dari komunikasi synchronous, komunikasi asynchronous, dan bulk data transfer.

Keuntungan implementasi antara lain penggunaan kembali service, pengembangan aplikasi yang lebih efisien, dan peningkatan kolaborasi. Hal ini termasuk pengambilan keputusan yang lebih 
sistematis mengenai penggunaan kembali dan target yang lebih spesifik untuk pengembang service. Tujuan penelitian ini untuk melihat apa saja yang harus perlu dilakukan untuk memperkenalkan SOA di perusahaan.

\section{METODE}

Penelitian ini menggunakan metode penelitian kualitatif berupa studi kasus. Bahan penelitian didapatkan lewat studi literatur dari berbagai sumber.

\section{HASIL DAN PEMBAHASAN}

\section{Solusi Teknologi Informasi}

Tantangan dalam industri perbankan memaksa bank untuk merenovasi sistem inti mereka untuk bertahan hidup persaingan sengit (Rong et al., 2013). CIO Credit Suisse membuat keputusan untuk mengatasi masalah di atas dengan mengenalkan sebuah arsitektur yang terintegrasi berdasarkan service-oriented architecture (SOA). Pendekatan yang dilakukan ternyata berhasil. Mereka mendefinisikan dan mengimplementasikan bus integrasi menurut kebutuhan yang paling mendesak dan langsung mendapatkan manfaat darinya.

Setelah sukses mengimplementasi bus informasi yang menyediakan komunikasi synchronous, Credit Suisse menambahkan bus event yang digunakan untuk integrasi backend to backend yang menyediakan komunikasi asynchronous. Bus kedua ini menggunakan prinsip yang mirip, tetapi menggunakan kriteria teknis yang sedikit berbeda dan oleh karenanya menyediakan keuntungan tambahan. Bahkan tipe ketiga bus integrasi beroperasi menggunakan transfer file untuk komunikasi.

\section{Arsitektur}

Arsitektur yang diimplementasikan menggabungkan tiga paradigma. CSIB yang digunakan untuk komunikasi synchronous yang digunakan untuk akses front-end ke aplikasi di dalam, event bus infrastructure (EBI) yang menggunakan komunikasi asynchronous untuk mengintegrasikan aplikasi baru yang tidak berada di dalam perusahaan, dan terakhir bulk integration infrastructure yang menggunakan transfer file untuk komunikasi.

\section{Integrasi Synchronous dengan CSIB}

Implementasi bus informasi dimulai dengan membuat struktur dari aplikasi yang ada menjadi sekitar 20 domain. Sebuah domain aplikasi menggabungkan semua data dan aplikasi yang dimiliki oleh suatu area bisnis. Gambar 2 menunjukkan bagaimana aplikasi dienkapsulasi ke dalam domain yang memiliki coupling ketat di dalam domain, tetapi longgar ketika berpindah domain karena menggunakan bus informasi.

Namun, CSG memutuskan tidak melakukan usaha untuk melakukan faktor ulang logika dalam domain atau antara domain, ketika komunikasi tidak melewati bus informasi. CSG memutuskan perubahan mendatang dari aplikasi yang ada akan merubah komunikasi dalam domain yang akan membuat hilangnya coupling infrastruktur tanpa memberikan dampak pada service yang sudah ada. 


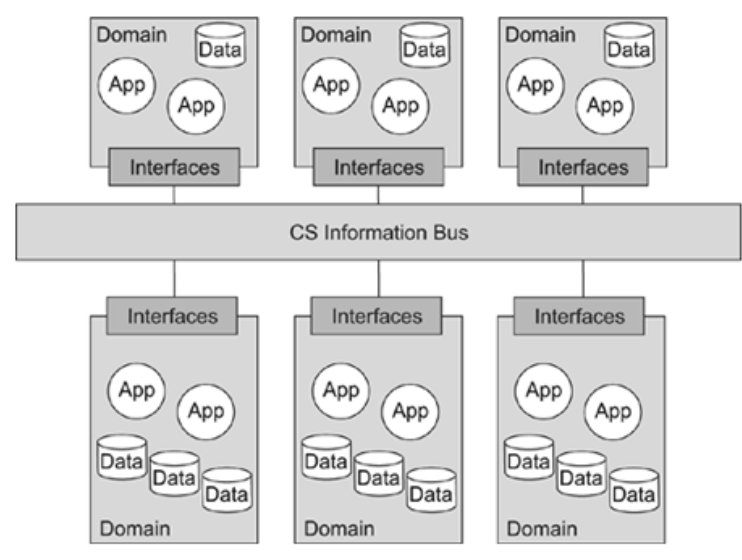

Gambar 2 Pembagian Aplikasi ke dalam Domain yang loosely coupled

Pertama kali CSIB diimplemntasikan menggunakan teknologi CORBA. Gambar 3 menyediakan gambaran detail bagaimana arsitektur awal dan teknologi pada layer lainnya.

The Credit Suisse Information BUS (CSIB)

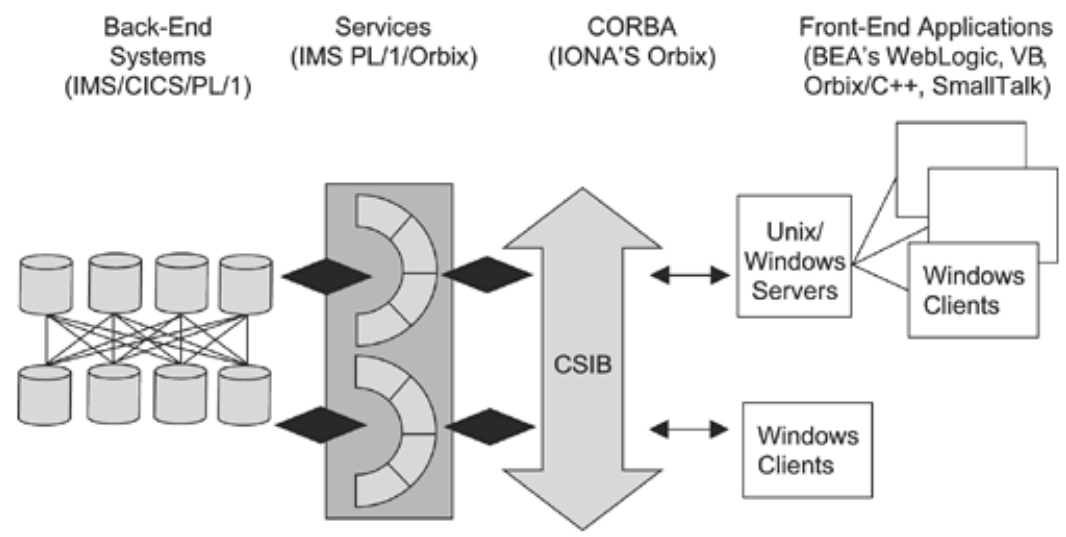

Gambar 3 Implementasi awal Credit Suisse information bus

Selain CORBA, DCE (Distributed Computing Environment) dan DCOM juga dievaluasi, tetapi tidak dipakai. Integrasi antara CORBA and EJB (Enterprise Java Beans) digunakan untuk implementasi aplikasi frontend. Karena abstraksi yang kuat pada teknologi yang sudah dipakai, CORBA sebenarnya bisa digantikan oleh teknologi lain, seperti Web service. Namun, sejauh ini CORBA bekerja dengan baik dan masih digunakan untuk implementasi service baru. Teknologi remote procedure call (RPC) seperti CORBA dan DCOM memungkinkan koneksi jarak jauh antara komponen yang berada di workstation dan server (Erl, 2005).

\section{Integrasi Asynchronous dengan EBI}

Di tahun 2000, ketika bus informasi bus telah sukses diimplementasikan, Credit Suisse memutuskan menambahkan platform integrasi kedua. Ide awalnya adalah untuk menangani integrasi aplikasi backend-to-backend (dalam satu domain atau antar domain) dengan konsep yang sama yang telah terbukti sukses ketika mengenalkan SOA dan bus informasi. 
Credit Suisse menyebutnya penambahan bus event sebuah generalisasi SOA pada arsitektur yang berbasis komponen. Istilah "service" digunakan pada bus informasi. Namun, pendekatan pada bus event lebih umum dan juga termasuk komunikasi asynchronous.

EBI menggunakan kembali semua konsep yang semua digunakan di CSIB Furthermore, CSIB dan EBI berbagi implementasi service yang sama, yang memfasilitsi penggunaan kembali logika bisnis dan live data sharing di luar lingkup sebuah infrastruktur tunggal yang membuktikan bahwa SOA di CSG benar-benar terlepas dari teknologi yang digunakan.

Infrastruktur bus event saat ini berupa solusi integrasi berbasis pesan yang mendukung routing berbasis topik dan transformasi seperti pada gambar 4 .

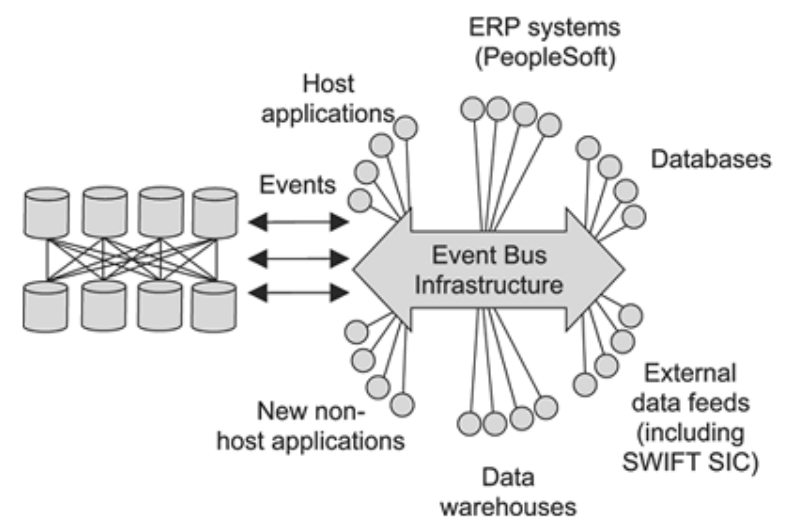

Gambar 4 Integrasi Arsitektur CSG termasuk bus event

Secara teknis EBI berbasiskan antrian pesan. Implementasi saat ini bergantung pada produk IBM, WebSphere suite. WebSphere MQ (MQ Series) menyediakan dasar yang bisa diandalkan untuk penyimpanan dan transportasi pesan, sementara WebSphere Business Integration Message Broker menyediakan fasilitas untuk trasnformasi pesan dan publish-and-subscribe. Credit Suisse secara khusus menekankan pentingnya manajemen interface dan contract. Keduanya ini harus dipenuhi untuk memisahkan ketergantungan aplikasi.

Pada kenyataannya, dasar dan proses pada bus event sama persis dengan di bus informasi. Ini tidak terbatas pada sifat abstrak dan desain dan proses pengembangan, tetapi juga detail teknis. Oleh karenanya, interface service untuk bus event dispesifikasikan dengan IDL (Interface Definition Language) dan event dan pesan menggunakan tipe informasi yang sama seperti bus informasi menggunakan kembali struktur data yang telah dimodelkan untuk service tersebut.

\section{Bulk Integration Infrastructure}

Bulk Integration Infrastructure adalah tipe bus software ketiga yang dikembangkan di CSG. Gambar 5 mengilustrasikan hubungan antara ketiga bus. Bus ketiga akan bertanggung jawab utuk manajemen konsisten untuk pertukaran data berbasiskan file.

Bus ketiga ini juga akan menggunakan kembali teknologi yang sama. Saat ini masih dalam pengembangan dan menggunakan transfer file point-to-point konvensional. Tujuannya menjadi perantara untuk kontrol tersentralisasi dari beragam transfer data dengan file. 


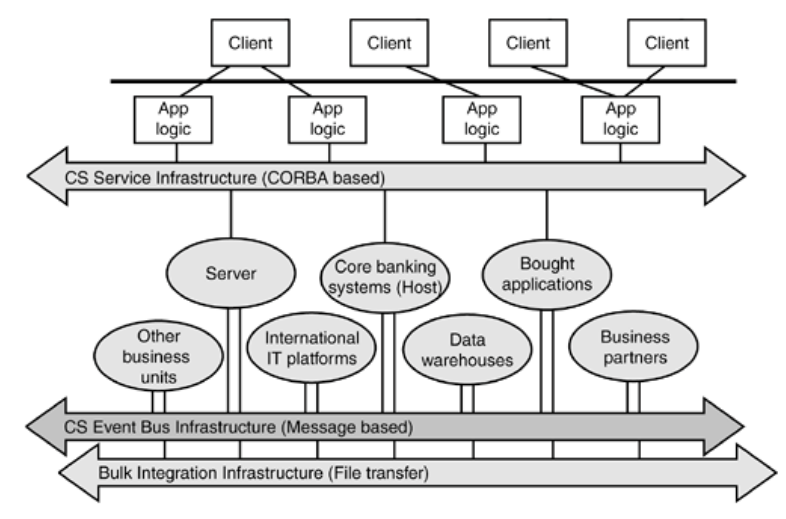

Gambar 5 Hubungan Antara Bus Informasi dan Bus Event

\section{Repositori, Service Interface, dan Contract}

Repositori dikembangkan oleh CSG dan berisi informasi tentang desain dan manajemen service dan events. Untuk setiap service, disediakan informasi berikut: (1) service interface, yaitu spesifikasi IDL; (2) properti, yaitu yang dimiliki oleh service, seperti efek pada data (misalnya, baca, tulis), ketersediaan (misalnya, publik, private), dan status saat ini (misalnya, tes, produksi); (3) perencanaan, yaitu informasi mengenai tanggal tes direncanakan atau dibuat dan tanggal service dioperasikan; (4) informasi kontak, yaitu informasi orang yang bisa dihubungi, misalnya pengembang, pemilik, desainer, dan atau pengguna; (5) detail implementasi, yaitu informasi tentang implementasi service seperti modul dan database yang digunakan; (6) kondisi service, yaitu deskripsi teks kondisi sebelum dan kondisi sesudahnya yang dijamin oleh service; (7) pengecualian, yaitu daftar kode yang tidak dipakai dengan sedikit penjelasan; (8) level service, yaitu informasi tentang waktu respon dan perkiraan permintaan per jam, hari, dan bulan (rata-rata dan maksimum); (9) deskripsi parameter, yaitu detail tentang argumen yang digunakan dan dihasilkan service.

\section{Choreography, Keamanan, dan Manajemen}

Implementasi SOA di Credit Suisse tidak termasuk solusi kompleks SOA untuk choreography, keamanan, atau manajemen.

Komponen workflow hanya digunakan untuk workflow yang melibatkan pengguna orang. Namun, pada level service tidak ada model proses eksplisit yang menyebabkan operasi service orchestrated ke dalam workflow yang kompleks. SOA di CSG bisa diklasifikasikan sebagai networked pada tahap ekspansi yang membedakan tahap kedewasaan SOA. Credit Suisse terus memonitor fungsionalitas yang terus meningkat yang disediakan dan mempertimbangkan penggabungan komposisi service dan model workflow untuk perkembangan SOA nya.

Solusi keamanan yang digunakan di Credit Suisse berdasarkan PKI (Public Key Infrastructure). Solusi PKI digunakan untuk integrasi internal saja pada saat ini. Integrasi Eksternal menggunakan koneksi terdedikasi.

Untuk mengatur distribusi service dan infrastruktur yang sudah ada beragam alat bantu digunakan. Alat bantu khusus CORBA mendukung manajemen sistem umum. Sebagai tambahan, Credit Suisse membuat alat bantu yang mengakses dan memproses data di sebuah komponen logging utama. Komponen logging berisi informasi detail tentang service yang dijalankan, termasuk informasi input data dan hasilnya ketika service dijalankan. 


\section{Pilot Project SOA}

Walaupun tidak ada rencana bisnis yang dibuat sebelum dikenalkannya SOA, keputusan implementasi ini dibuat langsung oleh CIO Credit Suisse. Implementasi juga berkaitan dengan dua proyek besar di Credit Suisse, yaitu rekonstruksi data center, yang diperlukan sejumlah besar merger dan akuisisi, dan membersihkan data warehouse. Pengenalan SOA dimulai dengan sebuah proyek pilot skala kecil di tahun 1997, tetapi telah ditetapkan dari awal bahwa akan digunakan untuk keseluruhan infrastruktur IT Credit Suisse.

\section{Lingkup Proyek}

Sitem pembukuan sentral di Credit Suisse menangani sekitar lima juta rekening dengan sekitar 218 juta pergerakan rekening per tahun. Arsitektur service Credit Suisse mencakup bisnis perbankan dan juga mencakup Winterthur, yang dimiliki oleh CSG yang juga memiliki infrastruktur IT sendiri berbasiskan SOA.

Credit Suisse memiliki infrastruktur IT tipikal seperti perusahaan finansial besar lainnya dan memiliki sekitar 600 aplikasi, sekitar 12 juta baris kode (untuk sistem inti) dan platform beragam (IBM mainframe, Unix, Windows). Awal mula sistem IT di tahun 70-an berupa aplikasi berbasis terminal. Pada akhir 80-an dan awal 90-an, aplikasi client/server ditambahkan, berdasarkan generator 4GL dan teknologi beriorientasi objek menggunakan Smalltalk. Dengan maraknya internet dan intranet, arsitektur multi-tier dibuat dan aplikasi baru kebanyakkan dibangun dengan Java. Namun, aplikasi mainframe tetap didukung dan diperbaharui dan tetap dipilih untuk aplikasi berorientasi transaksi. Lingkungan teknologi informasi yang berfokus pada mainframe merupakan arsitektur umum di banyak organisasi, terutama di industri finansial seperti bank.

\section{Dampak Bisnis}

Dari sudut pandang bisnis infrastruktur SOA harusnya menjadi dasar untuk: (1) kegiatan perbankan multi-channel; (2) online trading; (3) konsolidasi dengan portfolio aplikasi bisnis inti.

Sebagai fondasi SOA, Credit Suisse mendesain sebuah infrastruktur bisnis penting yang menyediakan: (1) manajemen dan administrasi tersentralisasi; (2) operasional 24 jam dan tujuh hari penuh; (3) mendukung terjadi beberapa ribu pengguna concurrent; (4) throughput yang tinggi; (5) waktu respon sub-second (di bawah satu detik)

Aplikasi yang dibangun pada infrastruktur baru diharapkan menyediakan akses kepada pelanggan lewat internet dan karyawan lewat intranet. Terakhir gateway tambahan dibangun untuk merealisasikan integrasi B2B dengan rekan bisnis lewat internet.

\section{Dampak Teknologi}

CSG memiliki lima tujuan utama ketika memperkenalkan arsitektur integrasi berbasis SOA: (1) integrasi teknis, yaitu pengaturan ketergantungan antara platforms secara teknis; (2) integrasi logis, yaitu pengaturan ketergantungan antara aplikasi dan komponen pada level semantik bisnis; (3) integrasi proses dan desktop, yaitu integrasi aplikasi yang beragam menurut proses bisnis dan workflow pengguna; (4) integrasi software yang dibeli, dalam hal ini perlunya metode dan alat bantu untuk mengintegrasikan software eksternal seefisien mungkin; (5) integrasi B2B, yaitu integrasi dengan rekan bisnis, supplier, dan pelanggan.

CSG mencapai kelima tujuan di atas dengan tiga tipe berbeda infrastruktur terintegrasi yang saling melengkapi disertai sebuah infrastruktur workflow untuk integrasi proses. Credit Suisse 
information bus yang mendukung komunikasi synchronous, event bus infrastructure yang mendukung komunikasi asynchronous, dan bulk integration infrastructure yang menggunakan transfer file sebagai basis untuk komunikasi. Bersamaan ketiga infrastruktur ini membentuk fondasi IT Credit Suisse, yang bertujuan menghubungkan aplikasi bisnis berdasarkan contract yang telah didefinisikan dengan jelas.

Gambar 6 menunjukkan pendekatan integrasi berdasarkan domain yang menjadi dasar Information Bus. Komunikasi melewati domain yang berbeda, seperti bagian penjualan, logistik, atau analisis data dicapai melalui information bus dan memastikan loose coupling antara domain tersebut.

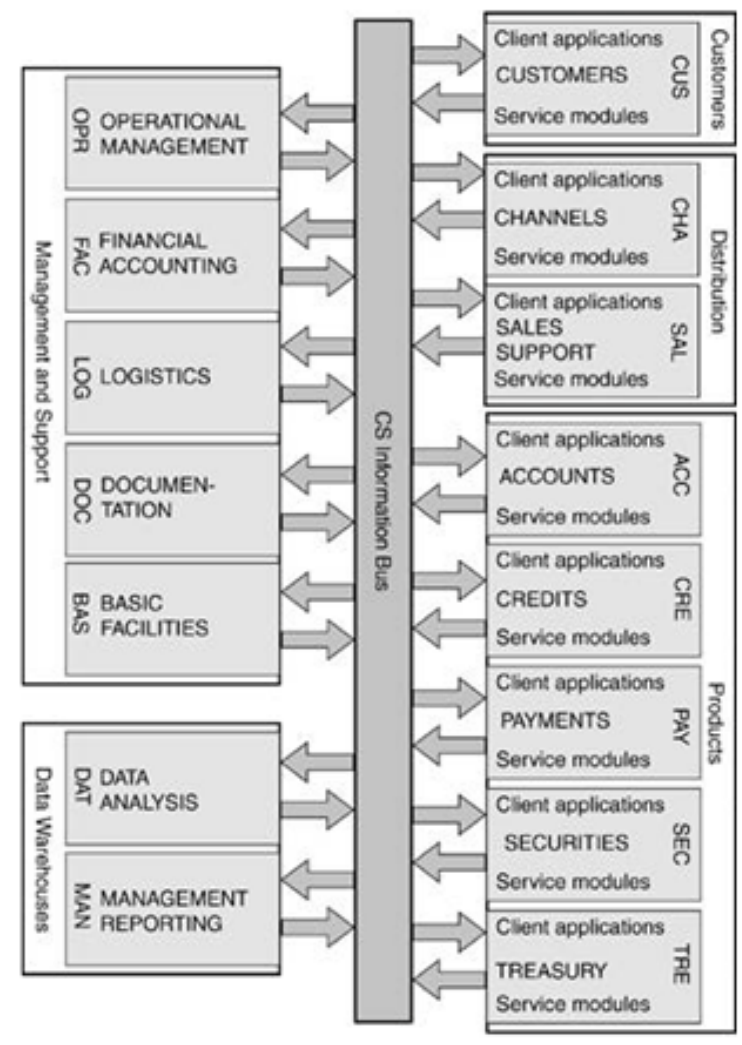

Gambar 6 Bus informasi menggabungkan domain yang berbeda

Seperti definisi dari komunikasi asynchronous, kriteria teknis utama menjamin sekali dan hanya sekali pengiriman pesan.

Service pada pengguna bisa meminta pesan dan implementasi service bisa merespon suatu saat kemudian. Service pada pengguna juga akan mengambilnya pada saat respon tersedia. Tidak ada penghalangan pada jalur informasi dan ada lebih banyak hal bisa dikerjakan paralel

Kebutuhan arsitektur utama untuk interaksi berdasarkan pesan adalah: (1) konektivitas asynchronous dan transformasi pesan; (2) diseminasi real-time data penting; (3) routing statis dan berbasiskan content; (4) publish dan subscribe berbasiskan topik; (5) point-to-point messaging; (6) peningkatan konsistensi data melewati aplikasi yang berbeda; (7) integrasi standar software.

\section{Implementasi SOA}

Walau dengan dukungan dari CIO beberapa ketidakpastian tetap terjadi, sebagian besar karena masalah teknis. Problem utama adalah kompleksitasnya dan biaya dan lamanya waktu yang 
ditimbulkan. Khususnya untuk memastikan penggunaan ulang service yang dianggap sebagai faktor utama yang menyebabkan peningkatan biaya pada proses mendesain. Sebagai tambahan keberatan teknis menggunakan CORBA (common object request broker architecture) yang merupakan dasar dari service bus CSG meningkat. Pada CORBA, sebagai ganti menyediakan server, yang mengekspos banyak fungsi yang bisa diakses secara remote, fungsionalitas dipecah sehingga bisa secara unik diidentifikasi, objek yang secara remote bisa mengatur state mereka sendiri. Para pengembang percaya bahwa metode ini terlalu banyak menghabiskan sumber daya, dan pengembang dengan Java berargumentasi bahwa pendekatan murni dengan J2EE akan lebih baik dan lebih disukai..

Namun, Credit Suisse menanggapi perlawanan ini dengan serius. Arsitektur ini diberikan sebuah posisi yang utama dan penting dalam departemen IT dan menegaskan bawah pengecualian dan penyimpangan dari pendekatan yang dipilih tidak akan ditoleransi. Penggunaan kembali diprioritaskan, didokumentasikan, dan secara agresif disosialisasikan, sepertinya juga sistem yang decoupling. Perjuangan ketat untuk menuju SOA dan aplikasi yang akurat membantu kesuksesan implementasi dan kebanyakkan personel yang keberatan menjadi yakin akan keuntungan SOA.

\section{Proses dan Struktur}

Credit Suisse membentuk dua tim infrastruktur untuk menerapkan arsitektur berbasiskan SOA. Tim pertama bertanggung jawab untuk membuat middleware yang diperlukan dan yang lain mendukung pengembang menggunakan teknologi. Tim-tim ini bertanggung jawab satu sama lain melalui tugas yang berkaitan dan didukung oleh arsitek integrasi dari departemen arsitektur utama (lihat Gambar 7).

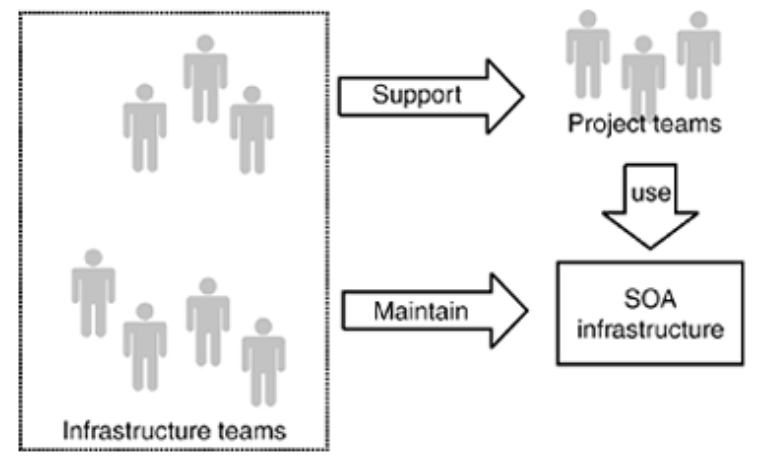

Gambar 7 Tim-tim yang mendukung proyek dan menjaga infrastruktur SOA

Pertama, tim-tim ini harus membuat detail proses dan struktur yang akan menyertai pengenalan SOA. Detail ini juga akan menyangkut persetujuan untuk service contract dan interface, sebagai tambahan selain definisi yang jelas untuk desain dan proses pengembangan untuk service.

Kedua, tim harus mensosialisasikan konsep ini dan mendukung pengembang dari unit bisnis yang berbeda dengan baik. Tantangannya adalah bagaimana untuk menjual konsep penggunaan kembali, yang pada awalnya hanya menimbulkan perspektif hanya akan menimbulkan lebih banyak biaya dan waktu.

Akhirnya tim-tim bertanggung jawab untuk meninjau ulang definisi service dan bertindak sebagai kendali mutu. Sekali lagi penggunaan kembali adalah konsep kunci di sini dan faktor yang membedakannya dengan manajemen proyek "tradisional". Tim tersebut harus memastikan bahwa pengembangan service harus diikuti dengan detail proses dan dipenuhinya kriteria yang diperlukan untuk integrasi arsitektur. Khususnya mereka harus memastikan bahwa unit bisnis tidak mengabaikan SOA dan mendapatkan ijin dari pihak manajemen untuk membuat "pengecualian”. 
Salah satu aspek penting dari SOA adalah membuat definisi proses yang jelas untuk pembuatan service. Proses ini dimulai dengan komunikasi antara konsumen service dan menghasilkan spesifikasi yang sangat detail. Berdasarkan spesifikasi, sebuah keputusan diambil untuk membangun service baru atau menggunakan service yang sudah ada, yang mungkin dimodifikasi atau dikembangkan untuk memenuhi kebutuhan aplikasi baru. Peninjau arsitektur meninjau ulang keputusan ini sebelum desain dan implementasi service bisa mulai dilakukan. Peninjau arstitektur sendiri terdiri dari designer berpengalaman yang dari grup utama arsitektur dan dari tim pendukung.

Pengembangan service berlanjut dengan pendekatan bottom-up yang ketat sebelum perencanaan dasar service dimulai. Sebaliknya sebuah service akan didefinisikan dan diimplementasikan ketika aplikasi tertentu membutuhkannya, seperti pada Gambar 8. Hal ini memungkinkan konstruksi arsitektur service dalam proses incremental dan efisien.

Pendekatan top-down berdasarkan definisi formal interface seperti IDL atau WSDL. Pendekatan bottom-up menganalisa kode dari implementasi service.

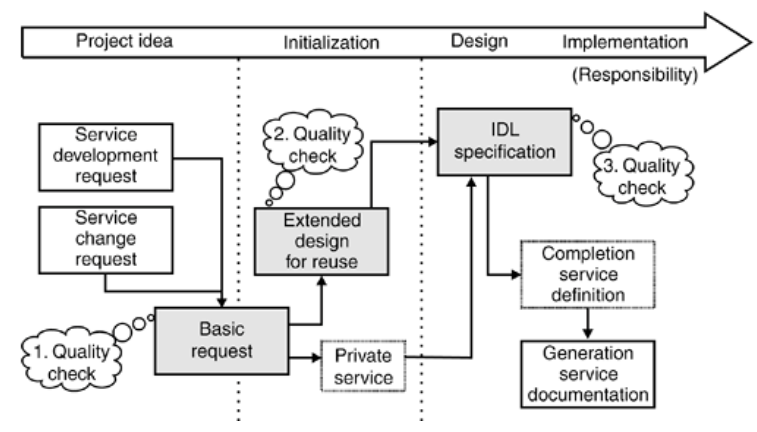

Gambar 8 Desain proses berdasarkan SOA di CSG: Permintaan dibuat secara bottom-up, dan kualitas dipastikan secara top-down

\section{Repository Service}

Credit Suisse menggunakan sebuah pusat repositori untuk mempublikasi semua informasi relevan tentang sebuah service. Repositori ini berisi deskripsi service pada level bisnis dan spesifikasi teknis interface berdasarkan IDL (Interface Definition Language CORBA).

Biasanya, grup pengguna yang berbeda memerlukan keduanya, tetapi di beberapa kasus, pertama pengembang mengakses deskripsi level bisnis untuk menghasilkan spesifikasi detail lalu deskripsi IDL pada saat fase implementasi yang sebenarnya.

Repositori juga berisi informasi mengenai pembaharuan service, yang khususnya penting untuk mengembangkan service Credit Suisse.

\section{Manajemen Proyek}

Seperti penjelasan sebelumnya, kompleksitas infrasttruktur IT CSG mencapai situasi kritis di akhir 90-an karena implementasi ulang dari fungsionalitas yang ada secara ekonomis dan teknis tidak mungkin. Pendekatan Managed Evolution diterapkan, yaitu dengan transformasi tahap demi tahap sitem yang ada ke sistem yang baru. Setiap proyek dalam tahapan ini diharapkan bisa mengkontribusikan kepada optimasi sturuktural sistem IT. 
Gambar 9 menggambarkan prinsip Managed Evolution yang berisi dua dimensi dasar dari infrastruktur IT, efisiensi IT dan nilai bisnis. Efisiensi IT menangkap seberapa cepat dan tidak mahalnya sistem bisa diubah. Nilai bisnis memberikan manfaat dari infrastruktur untuk pengguna, yaitu unit bisnis di perusahaan. Setiap proyek idealnya harus mengkontibusikan dua dimensi ini.

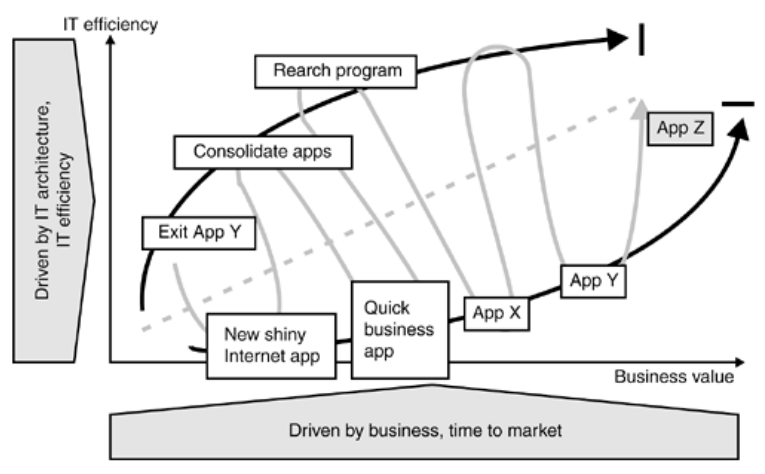

Gambar 9 Prinsip managed evolution

Untuk menjamin kontribusi pada level ini kepada keseluruhan arsitektur, kejelasan panduan, proses, dan struktur harus dibangun untuk membantu membedakan "kesempatan baik dari yang buruk". Credit Suisse memiliki tim khusus yang bertanggung jawab untuk panduan tersebut dan memonitor aplikasi mereka langsung di bawah CIO.

Metodologi yang digunakan di Credit Suisse untuk mengatur proyek bisnis kebanyakan berdasarkan model waterfall. Namun, faktor penting kesuksesan proyek tersebut adalah kendali atas penyerahan proyek, seperti spesifikasi tampilan dan koordinasi dengan tim infrastruktur yang sesuai.

\section{Hasil dan Keuntungan Implementasi SOA}

Aplikasi backend inti untuk integrasi sebagian besar berjalan di IMS (80\%) dan CICS (20\%) pada mainframe S/390 besar. Aplikasi ditempatkan pada server Unix dan Windows. Aplikasi frontend, yang sedang digunakan dan sebagian dalam pengembangan menggunakan J2EE, C++, Smalltalk, HTML, COM, dan Visual Basic.

Ketika Information Bus dioperasikan tahun 1999, lima aplikasi frontend ditempatkan, menyediakan 35 service ke sekitar 800 pengguna. Satu tahun kemudian, aplikasi yang didukung meningkat menjadi 21 dengan 173 service dan 9.000 pengguna. Angka ini meningkat drastis menjadi 500 service di tahun 2000, digunakan lebih dari 50 aplikasi frontend dan lebih dari 100.000 pengguna (termasuk baik pelanggan Internet banking dan staff internal).

Tahun 2004 bus informasi menawarkan lebih dari 700 service dan menangani antara 1,5 and 2 juta permintaan, dengan total 10 juta permintaan setiap minggu atau 50 juta per bulannya. Event Bus yang menangani sekitar 20 aplikasi memproses 500.000 pesan lainnya per hari.

Gambar 10 menunjukkan pengembangan service yang tersedia di Credit Suisse dari tahun 2000 sampai 2003. Gambar 11 menunjukkan perkembangan penggunaan service tersebut. Stagnasi yang terjadi pada tahun 2002 dan 2002 dikarenakan keadaan bisnis yang sulit. 


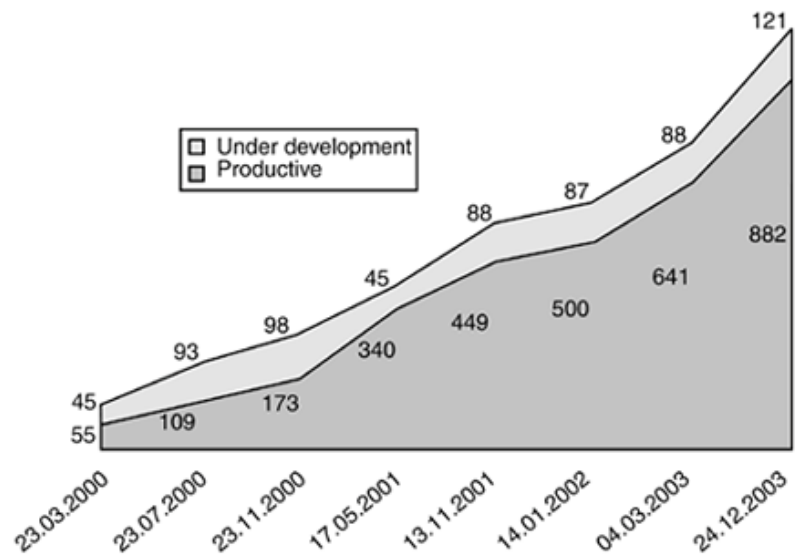

Gambar 10 Pengembangan service yang tersedia di CSG dari Tahun 2000 Sampai 2003

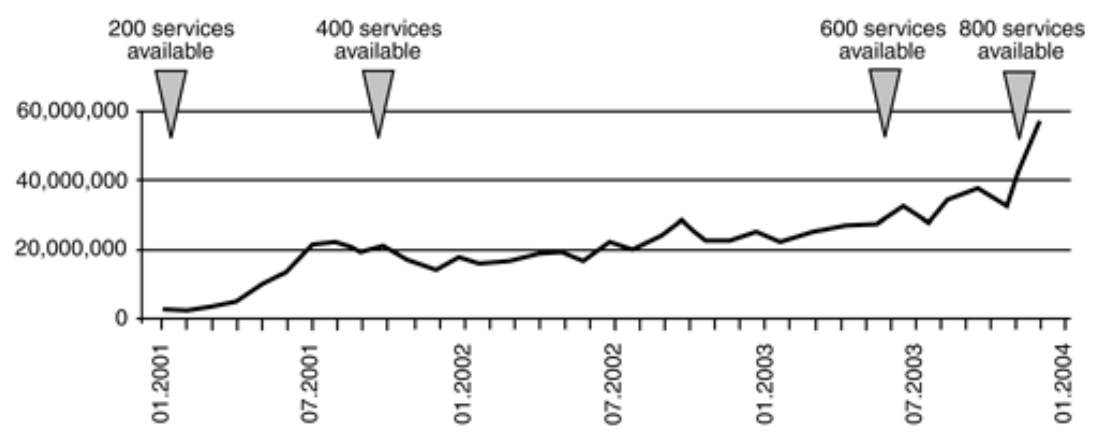

Gambar 11 Permintaan service di CSG dari tahun 2000 - 2003

Ada beberapa keuntungan utama yang dialami oleh CSG.

Pertama, penggunaan kembali service. Service bisnis digunakan di berbagai aplikasi. Walau tingkat rata penggunakan kembali hanya 1,6 ketika menghitung untuk keseluruhan service, tetapi beberapa service bisnis bisa digunakan kembali sampai 12 aplikasi. Rendahnya nilai rata-rata disebabkan fakta bahwa banya service saat ini sedang digunakan oleh satu aplikasi saja. Karena service pada mulanya dibangun ketika ada seorang pengguna yang memintanya, akan diperlukan waktu sebelum pengguna lain ingin menggunakannya. Penggunaan kembali didorong oleh repositori tersentralisasi yang berisi service interface dan dokumentasi yang detail.

Keuntungan kedua adalah pengembangan aplikasi yang lebih efisien. Karena banyak penggunaan kembali service, pengembangan aplikasi telah dipercepat dengan signifikan. Biasanya, ketika sebuah aplikasi dikembangkan, 75 sampai 80 persen dari service yang diperlukan telah ada di repository. Ini meningkatkan waktu yang diperlukan untuk mengimplementasikan solusi baru secara dramatis dan juga menawarkan penghematan biaya.

Keuntungan lainnya adalah peningkatan kolaborasi antara pengembang unit bisnis dengan programmer yang mengimplementasikan aplikasi bisnis inti. Juga dapat diamati, bahwa programmer PL/1 yang berpengalaman yang telah menjadi tidak termotivasi beberapa tahun ini menjadi aktif berpartisipasi dalam proses pengembangan. 


\section{PENUTUP}

Keuntungan yang didapat dari implementasi SOA tidak dicapai tanpa kerja keras. CSG mengalami adanya ketidakpastian secara kontinu mengenai pendekatan yang digunakan untuk mengintegrasikan arsitektur, misalnya keluhan bahwa CORBA terlalu menghabiskan banyak sumber daya, terlalu kompleks, dan terlalu lambat. Keberatan ini tidak disampaikan oleh semua pihak, tetapi dukungan konsisten dari pihak manajemen atas mengatasi hal ini.

Ada juga tahap kritis ketika Information Bus terancam gagal karena kesuksesannya. Semakin banyak pengguna mengakses aplikasi yang dibangun di atas CSIB, kinerja, keandalan, dan ketersediaaan menjadi harus selalu ada. Sekali lagi memiliki pihak manajemen yang mendukung dan anggaran yang mencukupi mengatasi masalah pada tahap kritis ini.

Juga diketahui bahwa decoupling yang belum dicapai untuk integrasi internal tidak harus dipenuhi untuk integrasi eksternal, yang menuntut persyaratan lebih.

Pada akhirnya, pendekatan bottom-up yang ketat diterapkan ke seluruh pengembangan SOA mungkin akan dilengkapi dengan pertimbangan mungkin akan dilengkapi dengan pertimbangan topdown di masa depan. Hal ini termasuk pengambilan keputusan yang lebih sistematis mengenai penggunaan kembali dan target yang lebih spesifik untuk pengembang service. Salah satu idenya adalah mengurangi biaya untuk mengembangkan service yang mungkin tidak akan digunakan. Aspek lain adalah indentifikasi service yang hilang, ketika mereka tidak secara langsung sedang dibutuhkan oleh sebuah aplikasi.

Credit Suisse menekankan empat aspek utama, yaitu interface, proses, komitmen manajemen, dan teknologi yang solid. Bukti dari kesuksesan integrasi arsitektur berbasis SOA adalah didasarkan fakta bahwa konsep dan metodologi yang pada awalnya dibangun untuk bus informasi synchronous bisa digunakan kembali satu per satu ketika memperkenalkan bus event. Lebih jauh lagi, implementasi integrasi struktur bulk juga didasari pada dasar yang sama. Hal ini mendemonstrasikan bahwa kedua konsep dan metodologi benar-benar menghasilkan hasil yang diinginkan dan bahwa ketiganya tidak terkait dengan teknologi yang dipakai.

\section{DAFTAR PUSTAKA}

Erl, T. (2005). Service-Oriented Architecture: Concepts, Technology, and Design. New Jersey: Prentice Hall.

Herr, M., Bath, U., \& Koschel, A. (2004). Implementation of a service oriented architecture at deutsche post MAIL. Lecture Notes in Computer Science, 3250, 227-238.

Rodriguez, Juan M., Crasso, M., Mateos, C., Zunino, A., Campo, M. (2013). Bottom-up and top-down cobol system migration to web services. Internet Computing, IEEE, 17 (2), $44-51$.

Rong Liu, Wu, F., Patnaik, Y., Kumaran, S. (2009). Business entities: an SOA approach to progressive core banking renovation. Services Computing, 2009. SCC '09. IEEE International Conference, 466 - 473, 21-25 Sept. 